\title{
The role of HCV proteins on treatment outcomes
}

\author{
Kattareeya Kumthip and Niwat Maneekarn ${ }^{*}$
}

\begin{abstract}
For many years, the standard of treatment for hepatitis $\mathrm{C}$ virus (HCV) infection was a combination of pegylated interferon alpha (Peg-IFN-a) and ribavirin for 24-48 weeks. This treatment regimen results in a sustained virologic response (SVR) rate in about $50 \%$ of cases. The failure of IFN-a-based therapy to eliminate HCV is a result of multiple factors including a suboptimal treatment regimen, severity of HCV-related diseases, host factors and viral factors. In recent years, advances in HCV cell culture have contributed to a better understanding of the viral life cycle, which has led to the development of a number of direct-acting antiviral agents (DAAs) that target specific key components of viral replication, such as HCV NS3/4A, HCV NS5A, and HCV NS5B proteins. To date, several new drugs have been approved for the treatment of HCV infection. Application of DAAs with IFN-based or IFN-free regimens has increased the SVR rate up to $>90 \%$ and has allowed treatment duration to be shortened to 12-24 weeks. The impact of HCV proteins in response to IFN-based and IFN-free therapies has been described in many reports. This review summarizes and updates knowledge on molecular mechanisms of HCV proteins involved in anti-IFN activity as well as examining amino acid variations and mutations in several regions of HCV proteins associated with the response to IFN-based therapy and pattern of resistance associated amino acid variants (RAV) to antiviral agents.
\end{abstract}

Keywords: Antiviral agent, Hepatitis C virus, Interferon, Mutation, Ribavirin

\section{Background}

Hepatitis C virus (HCV) belongs to the Hepacivirus genus which is part of the Flaviviridae family. HCV is a small enveloped virus with a positive single-stranded RNA genome containing approximately 9,600 nucleotides which encodes for a large polyprotein of about 3,000 amino acids. The polyprotein precursor is cleaved by the host and viral proteases into three structural proteins (core, E1, E2) and seven nonstructural proteins (p7, NS2, NS3, NS4A, NS4B, NS5A, NS5B) [1, 2] (Fig. 1). $\mathrm{HCV}$ core protein is a highly conserved RNA-binding protein, which presumably forms the viral nucleocapsid and plays a role in pathogenesis [3-5]. E1 and E2 envelope glycoproteins are essential components of the $\mathrm{HCV}$ virion and necessary for viral entry and fusion $[6,7]$. P7 could act as a calcium ion channel and has an important role in viral maturation and release $[8,9]$. NS2 is a transmembrane protein required for NS2/3 autoprotease activity that cleaves the site between the NS2 and NS3

\footnotetext{
* Correspondence: niwat.m@cmu.ac.th

Department of Microbiology, Faculty of Medicine, Chiang Mai University, Chiang Mai 50200, Thailand
}

junction [10-12] while NS3 is the protease and NTPase/ helicase $[13,14]$. NS4A serves as a cofactor of the NS3 protease activity and NS4B functions as a membrane anchor for the replication complex $[15,16]$. NS5A is a hydrophilic phosphoprotein needed for viral replication $[17,18]$. NS5B, a RNA-dependent RNA polymerase (RdRp), is a key enzyme for viral replication promoting synthesis of new RNA genomes [19, 20]. With the lack of a proof-reading activity and error correction mechanisms of the viral $R d R p$, the high genetic variability and high degree of mutation rate of the $\mathrm{HCV}$ are occurred, allowing for rapid adaptation and lead to a genetically variant pool of viruses within the infected individual $[21,22]$. Due to the diversity of the genome, $\mathrm{HCV}$ is classified into 7 major genotypes and 67 subtypes [23]. $\mathrm{HCV}$ genotypes are distributed in different parts of the world. Genotypes 1-3 are widely distributed throughout the world, genotypes 1 and 2 are endemic in West Africa while genotype 3 is endemic in India. Genotypes 4 and 5 are prevalent in Africa and genotype 6 in Southeast Asia. The distribution of genotype 7 has not been fully evaluated $[24,25]$. 


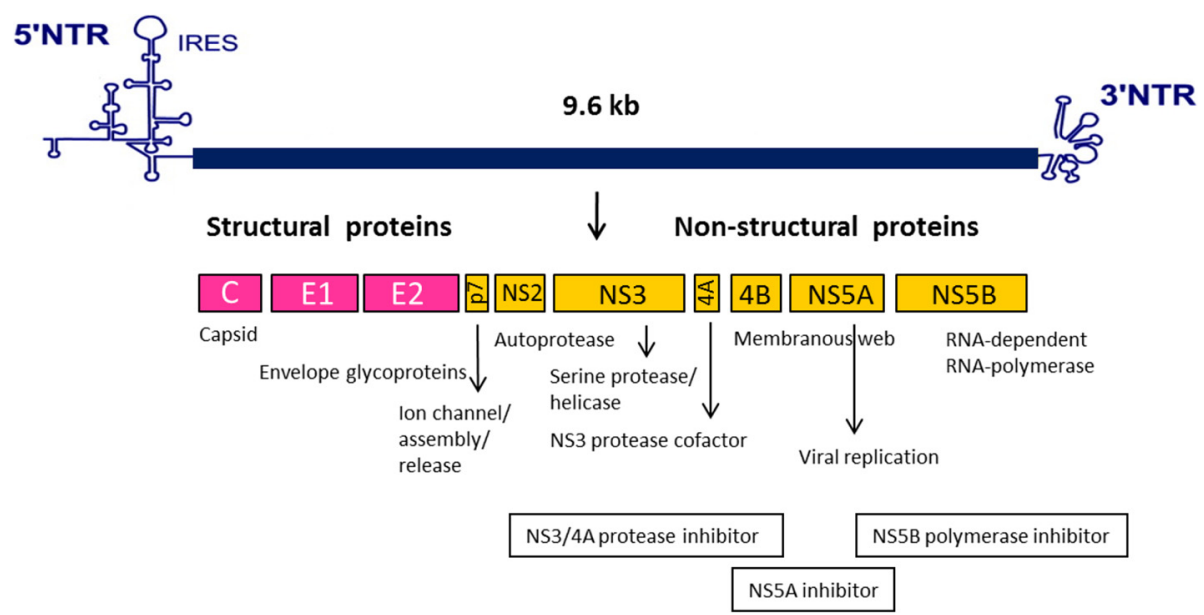

Fig. 1 HCV genomic organization, HCV proteins and targets for direct-acting antiviral agents. The HCV genome, having approximately 9.6 kilobases (kb), contains a 5'-nontranslated region (NTR), an internal ribosome entry site (IRES), a long open reading frame encoding polyprotein precursor of about 3,000 amino acid residues and a 3'-NTR. The polyprotein precursor is processed by both host and viral enzymes to release functional structural and non-structural proteins. HCV NS3/4A, HCV NS5A, and HCV NS5B are targets for antiviral agents [1, 2]

Life cycle of HCV includes entry into the host cell, uncoating of the viral genome, translation of viral proteins, polyprotein processing, viral genome replication, assembly and release of virions. All these events occur outside the nucleus of the host cell [26]. Following initial binding of the $\mathrm{HCV}$ particle to the host cellular receptors, scavenger receptor class B member 1 (SRB1) [27] and CD81 [28] via the E2 glycoprotein, the particle engages in further interactions with several entry factors including tight junction proteins claudin 1 (CLDN1) [29], occludin (OCLN) [30], epidermal growth factor receptor (EGFR), the ephrin receptor [31], and finally enters cells by receptor-mediated endocytosis. The viral RNA genome is released into the cytoplasm and subsequently translated at the rough endoplasmic reticulum (ER). After translation, the viral proteins, in conjunction with host cell factors, induce the formation of a membranous web where the RNA genome replication occurs [26]. The positive sense RNA genome is generated through a negative strand intermediate and is packaged into the viral particle containing the core and envelope proteins which accumulates to the ER and lipid droplets [32]. HCV virions are presumably formed by budding through the ER, or an ER derived compartment, and are exited the cell via the secretory pathway [33].

$\mathrm{HCV}$ infection occurs globally and remains a serious health problem worldwide. Nowadays, about 150 million people, representing $2-3 \%$ of the world's population, are chronically infected with $\mathrm{HCV}$ and more than 350,000 people die from HCV-related liver diseases each year [34]. The severity of $\mathrm{HCV}$ infection ranges from a mild illness to a serious sickness that leads to chronic hepatitis, liver cirrhosis and hepatocellular carcinoma (HCC). Only a minority of $\mathrm{HCV}$-infected patients can clear the virus spontaneously during acute infection [35]. Innate immune responses are the first line of defense against viral infections and interferons (IFNs) are important cytokine responsible for the induction of an antiviral state of the cells for elimination of $\mathrm{HCV}$ during acute infection [36]. However, the majority of patients are unable to clear the virus. Approximately $50-80 \%$ of acute $\mathrm{HCV}$ infections persist and progress into chronic infection and approximately $4-20 \%$ of patients with chronic hepatitis $C$ develop liver cirrhosis within 10-20 years. Annually, about $1-5 \%$ of patients with cirrhosis are at risk of developing HCC" [35]. The viral persistence is related to both host and viral factors. The virus has developed several strategies to escape host innate immune responses by different mechanisms [37]. The mechanisms that protect $\mathrm{HCV}$ from IFN-mediated innate immune reactions are not completely understood, but involve interruption of IFN induction pathway, IFNstimulated genes (ISGs) production, or direct antagonism of effector systems by viral proteins [37, 38]. A protective vaccine for $\mathrm{HCV}$ infection is not available yet and although therapeutic options are improving they are still limited as well as some patients still resist to the treatment. Development and improvement of antiviral therapies and effective vaccines are still needed.

\section{Treatment of HCV infection and rate of response}

For many years, the combination of IFN- $\alpha$ and ribavirin was the approved treatment regimen for chronic $\mathrm{HCV}$ infection. IFNs are a family of cytokines released by host cells in response to various stimuli including virus infection. IFNs induce expression of multiple antiviral effector proteins working against virus replication [36]. IFN- $\alpha$ therapy leads to a rapid decline in HCV RNA 
levels in serum $[39,40]$. Ribavirin is a nucleoside analogue and possesses activity against several RNA and DNA viruses, however, the exact mechanism of action of ribavirin against HCV is still unknown [41]. The combination of IFN- $\alpha$ and ribavirin therapy led to great improvements in SVR rates [42-44].

Further improvement was achieved by the development of pegylated interferon alpha (Peg-IFN- $\alpha$ ), in which a large molecule of polyethylene glycol is covalently attached to recombinant IFN- $\alpha$ resulting in an active molecule with a longer half-life, better pharmacokinetic profile, and better rate of virologic response $[45,46]$. The commercially available forms of IFN- $\alpha$ used for hepatitis $C(\alpha 2 a, \alpha 2 b$ and consensus IFN) have somewhat different potencies in vitro but appear to yield similar response rates in treated patients $[47,48]$. For patients who are chronically infected with $\mathrm{HCV}$, the former standard of care recommendation was to use Peg-IFN- $\alpha$ plus ribavirin for 48 weeks for patients infected with genotype 1 or 24 weeks for patients infected with genotype 2 or 3 and for genotypes 4, 5 and 6 , it has been suggested that patients were treated in a similar manner as those for patients with genotype 1 [46]. This treatment regimen led to SVR rates ranging from 42 to $46 \%$ in patients infected with genotype $1,76-80 \%$ in patients infected with genotype 2 or 3 , and $50-77 \%$ in patients infected with genotypes 4, 5, and 6 [48-50]. Overall sustained responses occur in about one-half of patients but the likelihood of response varies greatly, depending on viral and host characteristics [51, 52]. The key host factors associated with response to IFN include IL28B genotype, race, and fibrotic stage $[53,54]$ while viral load and viral genotype are important viral factors associated with SVR [52, 54]. In addition, many problems associated with IFN-based regimens such as considerable sideeffects, expense, and length of treatment lead to many patients not being able to tolerate the full course of treatment, leading to treatment failure [55].

Since 2011, a number of direct acting antiviral agents (DAAs), which specifically target hepatitis $\mathrm{C}$ viral proteins including NS3/4A, NS5A and NS5B, have been used to improve the treatment of $\mathrm{HCV}$ infection. First generation NS3/4A protease inhibitors, including telaprevir and boceprevir, were approved by the United States Food and Drug Administration (FDA) for HCV genotype 1 infection in 2011 [56-59]. Both compounds were approved as triple combinations with Peg-IFN- $\alpha$ and ribavirin, and this regimen increased SVR rates in HCV genotype 1 infected patients to $66-75 \%$ among patients who had not previously received treatment for their infection (treatment-naïve) and 59-64\% in patients who had not responded to previous treatment (treatmentexperienced) [56-60]. A second-generation NS3/4A protease inhibitor, simeprevir [61], was approved in 2013. By using simeprevir in combination with Peg-IFN- $\alpha$ and ribavirin, the rates of SVR in treatment-naïve $\mathrm{HCV}$ genotype 1 infected patients were 75-85\% [62-64].

Several NS5A inhibitors have been reported such as ledipasvir (formerly GS-5885) [65], ombitasvir, formerly known as ABT-267 [66], and daclatasvir (BMS-790052) [67]. Ledipasvir and daclatasvir were approved in 2014 for use in combination with sofosbuvir (NS5B inhibitor). Triple therapy with Peg-IFN- $\alpha$, ribavirin, and the NS5A inhibitor daclatasvir led to SVR in $59-100 \%$ of treatmentnaïve $\mathrm{HCV}$ genotype 1 and 4 infected patients, according to drug dosage and HCV genotype [68].

There are 2 types of NS5B inhibitors, nucleoside/ nucleotide analogs and non-nucleotide analogs. Nucleotide analogs such as mericitabine [69] and sofosbuvir [70] act as false substrates for the HCV-RdRp and this leads to chain termination after being incorporated into the newly synthesized viral RNA [71, 72], and nonnucleotide analogs, such as dasabuvir [73] bind to several discrete sites on the NS5B polymerase, which leads to conformational protein changes. Sofosbuvir was approved in 2013 as part of a combination treatment with IFN and ribavirin and demonstrated extraordinary efficacy for treatment-naïve patients infected with $\mathrm{HCV}$ genotype 1 and 4 with $90 \%$ of SVR rate [74-76]. The use of triple IFN-containing regimens with the DAAs is associated with side effects that can be severe. The IFNfree regimens have been further considered by using a combination of several DAAs with or without ribavirin. For example, the combination of sofosbuvir plus ribavirin in genotype 2 infected patients for 12 weeks showed an SVR rate of about 95-97 \% [77].

In October 2014, the FDA approved Harvoni as the first DAA combination drug that does not require administration in combination with interferon or ribavirin. This daily, single tablet drug consists of the NS5A inhibitor (ledipasvir) and the NS5B polymerase inhibitor (sofosbuvir). In phase III clinical trials which enrolled 1,518 participants including treatment-naïve, treatmentexperienced and patients with cirrhosis, it was shown that these groups of patients achieved an SVR rate of between 96 and $99 \%$ within 12-14 weeks of the administration of the drug $[78,79]$. This new IFN-free therapy allows for a simplified and shortened therapy duration to $12-24$ weeks for all HCV genotypes.

\section{HCV proteins which mediate IFN resistance}

IFNs are cytokines which are part of the host's natural immune response to the presence of pathogens, such as viruses, bacteria, parasites or tumor cells [36]. After the binding of IFNs to their specific receptors on the target cell surface, an intracellular signaling cascade, the Janus kinase (Jak) and signal transducer and activator of transcription (STAT) pathway is activated. This leads to the up-regulation of a number of IFN-stimulated genes 
(ISGs) and expression of multiple antiviral effector proteins to eradicate the virus [80-82] (Fig. 2). IFN- $\alpha$ was first shown to have beneficial effects in patients with chronic HCV infection in 1986 [40] and has been used for treatment of $\mathrm{HCV}$ infection until now. The failure of IFN- $\alpha$-based treatment to eradicate $\mathrm{HCV}$ infection is influenced by multiple factors [51, 54]. It is believed that host factors and viral factors, particularly viral load and $\mathrm{HCV}$ genotype are important factors contributing to the difference in response to the IFN therapy [83]. HCV genotype 1 infected patients achieve poorly sustained rates of response (42-52\%) to IFN- $\alpha$-based therapy compared to those infected with $\mathrm{HCV}$ genotypes 2 and 3 (78-86 \%) [52]. So far, it has been suggested that several $\mathrm{HCV}$ proteins are responsible for the inhibition of the antiviral effects of IFN- $\alpha$ [84]. The expression of the whole $\mathrm{HCV}$ polyprotein as well as single $\mathrm{HCV}$ proteins of core, E2, NS3/4A, NS4B or NS5A have been shown to antagonize the antiviral effect mediated by IFN- $\alpha$ in many different ways as summarized in Fig. 2.

\section{HCV core}

The core protein of HCV interferes with the IFN signaling pathway. It has been shown that the HCV core induced the expression of the suppressor of the cytokine signaling protein 3 (SOCS-3) and SOCS-1 in cultured cells, which in turn antagonized IFN- $\alpha$ action by blocking the Jak/STAT pathway and the expression of ISGs $[85,86]$. The effect of core protein on the down-regulated expression of IFN-induced antiviral genes was described [87]. Additionally, the inhibitory effects of the $\mathrm{HCV}$ core protein on IFN-induced phosphorylation and nuclear translocation of STAT1 in cell cultures were demonstrated. The HCV core protein binds directly to STAT1, suggesting a model by which the binding of HCV core to STAT1 resulted in the decrease of STAT1 phosphorylation and disruption of ISGs transcription $[88,89]$.

\section{HCV E2}

The E2 protein of $\mathrm{HCV}$ was reported to be involved in mediating IFN- $\alpha$ resistance through the inhibition of protein kinase R (PKR) [90]. HCV E2 contains a peptide of eight amino acids that are identical to a sequence in PKR, four of which act as autophosphorylation sites in PKR. Next to this region, E2 contains another consecutive stretch of four amino acids identical to the phosphorylation site of the eukaryotic initiation factor 2 alpha subunit (eIF2 $\alpha)$ [82]. This region is known as the PKR-eIF2 $\alpha$ phosphorylation homology domain (PePHD). Binding of the PePHD derived from HCV genotype 1 to the cellular PKR abolishes its kinase activity and blocks its inhibitory effect on protein synthesis in vitro [90]. This may lead to viral protein translation taking place during virus infection and IFN treatment. However, these effects were not detectable for PePHD sequences derived from HCV genotypes 2 and 3 . It has been hypothesized that the interaction of the PePHD with the PKR may result in a relatively enhanced resistance of HCV-1 isolates to IFN- $\alpha$-based antiviral therapy [90].

\section{HCV NS3/4A}

The HCV protease disrupts the innate immune response and IFN induction pathway. IFNs are induced in the presence of the HCV viral genome sensing by patternrecognition receptors, retinoic acid inducible gene I

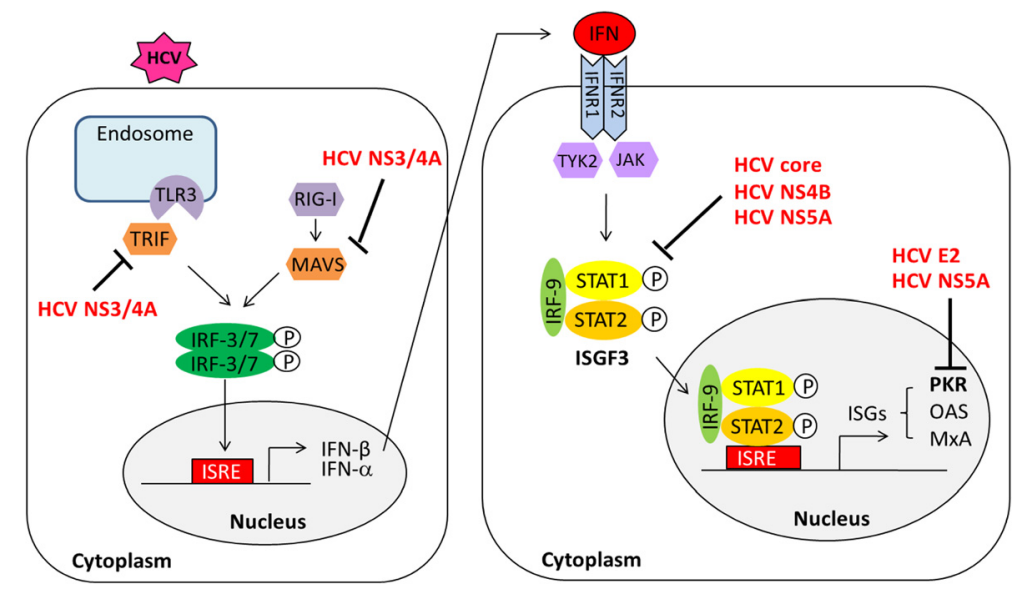

Fig. 2 Classical pathways of type I IFN induction and HCV mediating IFN resistance. HCV dsRNA is detected by the retinoic acid inducible gene I (RIG-I) and the toll-like receptor 3 (TLR3) and subsequently triggers the cascade of adaptor proteins, mitochondrial antiviral signaling protein (MAVS) and TIR-domain containing adapter-inducing interferon- $\beta$ (TRIF), respectively. This leads to the activation of the type I IFN induction pathway. Binding of IFNs to their cellular receptors activates an intracellular signaling cascade via the Jak/STAT signaling pathway and leads to the up-regulation of a number of interferon-stimulated genes (ISGS) expression [80-82] 
(RIG-I) and toll-like receptor proteins (such as TLR3) $[37,91]$. It was shown that $\mathrm{HCV}$ NS3/4A protease cleaves host proteins including the mitochondrial antiviral signaling protein (MAVS) [92, 93], and the TIRdomain containing adapter-inducing interferon- $\beta$ (TRIF) [94], adaptor proteins of RIG-I and TLR3 signaling pathways, respectively. This leads to inhibition of the innate immune response and the IFN induction pathway. The HCV NS3/4A protein has also been shown to block the phosphorylation and nuclear translocation of the interferon regulatory factor 3 (IRF-3), a key component of the downstream signal of both RIG-I and TLR3 resulting in a significant reduction of the transcription of IFN- $\alpha$ inducible genes $[95,96]$.

\section{HCV NS4B}

It has been shown that the expression of HCV NS4B in cell culture inhibited the protection of the cells by IFN- $\alpha$ treatment from vesicular stomatitis virus infection. The NS4B protein of HCV reduced the IFN- $\alpha$-induced phosphorylation level of STAT1 and the expression levels of type I interferon receptors and a reporter driven by the IFN-stimulated response element (ISRE) promoter [97].

\section{HCV NS5A}

The NS5A protein of HCV binds to and inactivates PKR in vitro. This binding is dependent on the PKR binding domain (PKRBD, codons 2209-2274) [98, 99]. This interaction presumes to allow viral protein synthesis to occur during IFN treatment. A number of studies have demonstrated the inhibitory effects of HCV NS5A protein on the IFN-induced Jak/STAT signaling pathway [100-103]. It has been shown that HCV NS5A blocked the ISRE promoter activity and IFN-induced STAT1 phosphorylation and its nuclear translocation resulted in inhibition of the IFN-induced ISGs expression [100, 101, 103]. It has been proposed that the interaction between the C-terminal region of NS5A and STAT1 is responsible for the anti-IFN activity of NS5A [102, 103].

\section{Amino acid variations associated with the response to IFN-based therapy}

In addition to the study of how HCV proteins counteract IFN activity, cloning and sequencing approaches for $\mathrm{HCV}$ isolates derived from patient sera with known virologic responses to antiviral therapy have been investigated. The clinical importance of amino acid variability within several functional regions of $\mathrm{HCV}$ proteins such as core, E1, E2, NS3, NS4B, NS5A and NS5B in correlation with the responses to IFN therapy have been described [104-143].

\section{HCV core}

The significance of amino acid mutations in the core protein of $\mathrm{HCV}$ and the response to IFN-based therapy has been described well in genotype 1b. Previous studies have demonstrated that substitutions of amino acid residues 70 (R70Q) and/or 91 (L91M) in the core region were significant factors independently associated with a non-virological response (NVR) to IFN and ribavirin combination therapy $[104,105]$. Substitutions in this region were also used for predicting the response to IFN in Japanese patients with HCV genotype 1b [106]. Moreover, the HCV core mutants R70 and L91 were shown to be resistant to IFN in vitro. Theses mutants were associated with a decrease in IFN-induced phosphorylation of STAT1 and STAT2, and the expression of ISGs through enhancement of the expression of SOCS-3 and interleukin $6[107,108]$.

\section{HCV E1/E2}

Several studies have demonstrated that mutations within the PePHD of the E2 protein of HCV genotypes $1 \mathrm{~b}$ and 3a showed no correlation with the clinical outcomes in patients treated with IFN- $\alpha$ [109-112]. However, it has been demonstrated that PePHD of genotypes $2 \mathrm{a}$ and $2 \mathrm{~b}$ had multiple amino acid variations and one particular motif, "RGQQ-" at the N-terminus of PePHD showed a close relationship with IFN resistance [113]. Another study showed that the presence of substitutions in a $\mathrm{N}$-terminal variable region (codons 617-641) in the Cterminal region of E2 showed a significant correlation with a low viral load and a sustained response to IFN treatment [114]. Furthermore, a study into recombinant $1 \mathrm{a}$ and $3 \mathrm{a} \mathrm{HCV}$ genotypes identified that amino acid substitutions at positions 345 and 348 of E1 and 414 of E2 increased IFN- $\alpha$ resistance [115]. It was shown that amino acid changes I348T in E1 protein of $\mathrm{HCV}$ genotype 1a (H77), F345V in E1 and V414A in E2 of genotype 3a (S52) increased viral fitness and that I348T and F345V/V414A mutants enhanced viral entry and release, respectively [115].

\section{HCV NS3}

In the $\mathrm{HCV}$ replicon system, several mutations within the NS3 gene that led to the enhancement of replication efficiency have been reported. The HCV isolates from patients harboring amino acid substitutions in the NS3 protein (R1283G, P1112R, and S1496M) showed a slower decrease of HCV RNA than those without mutations at those positions during IFN- $\alpha$-based therapy [116]. Additionally, it has been reported that the HCV 1b-infected patients with a better anti-IFN response ( $>3.5 \log$ decline of viral RNA by day 28) have higher number of amino acid substitutions in the NS3 protein than those of the patients with a poor response $(<1.4 \log$ 
decline of viral RNA by day 28) [117]. Recently, it has been demonstrated that increases in amino acid variations in the NS3 protein of HCV genotypes $1 \mathrm{a}, 1 \mathrm{~b}, 3 \mathrm{a}$, and $3 \mathrm{~b}$ are associated with the response to Peg-IFN and ribavirin combination therapy [118]. Amino acid variations within the full-length NS3, particularly in protease and helicase domains of NS3 of HCV genotype 1a, as well as the fulllength NS3/helicase domain of HCV genotype $1 \mathrm{~b}$ from responding patients treated with Peg-IFN and ribavirin are significantly more frequent than those from treatment failure groups [118]. In addition, use of an HCV replicon cell line which was exposed to IFN- $\alpha$ and IFN- $\beta$ revealed that substitutions S1269Y, K1270R, and R1135K in NS3 protein were associated with IFN resistance [119]. The possible reasons that may explain why these mutations may lead to IFN resistance based on the fact that NS3 is known as a bifunctional enzyme with serine protease activity on the $\mathrm{N}$-terminal domain and RNA helicase on its C-terminal domain [120]. The NS3 helicase is essential for HCV RNA replication and also plays a role in viral particle assembly [121]. Conceivably, amino acid substitutions in this region or particular position may affect the function of NS3 and contribute to the acquisition of IFN resistance. Correspondingly, Numba et al. [119] also described these amino acid substitutions of S1269Y, K1270R, and R1135K in the NS3 may contribute to the acquisition of IFN resistance. To clarify these points, further analysis, such as the characterization of HCV replicon cells re-established by the transfection of these $\mathrm{HCV}$ replicon RNAs into Huh7 cells, will be necessary [119].

\section{HCV NS4B}

Genetic analysis of $\mathrm{HCV}$ replicon cells resistance to IFN- $\alpha$ and IFN- $\beta$ exposure revealed that they all share a single common amino acid substitution in the NS4B $(\mathrm{Q} 1737 \mathrm{H})$ suggesting that these genetic alterations are involved in their IFN-resistant phenotype [119]. In addition, a rapid initial HCV RNA decline of $\geq 1.5 \mathrm{log}$ $10 \mathrm{IU} / \mathrm{mL}$ at week 2 of IFN-based therapy is associated with a higher frequency of non-conservative amino acid exchanges within the complete NS4B protein when compared to patients with a non-rapid $\mathrm{HCV}$ RNA decline [122].

\section{HCV NS5A}

The initial data which supported a significant role of amino acid variations within the NS5A protein of $\mathrm{HCV}$ and the response to IFN therapy was first described by Enomoto et al. in [123]. A correlation of a high number of mutations in a IFN- $\alpha$ sensitivity determining region (ISDR; codons 2209-2248) (Fig. 3) comprising 40 amino acids within the C-terminal part of the NS5A protein and SVR to IFN- $\alpha$ monotherapy in HCV genotype $1 \mathrm{~b}$ infected patients was described in Japan [124]. The viruses obtained from patients who achieved an SVR showed at least four mutations within the ISDR. Subsequently, the correlation of ISDR mutations with the response to IFN treatment was investigated by different groups in Japan, Europe and the United States. Many of the studies were from Japan and were able to confirm the strong correlation between ISDR mutations and treatment response [114, 125-128]. However, contradictory data have been reported from other parts of the world, particularly from Europe and the United States. The correlation of ISDR mutations with IFN- $\alpha$ sensitivity was not able to be verified [111, 129-132]. The discrepancy may be explained, at least in part, by host and viral factors. It is well documented that host factors, particularly the race of the subjects, are important factors contributing to HCV treatment responsiveness [133]. In addition to ISDR, the composition and number of mutations found in the interferon and ribavirin resistance determining region (IRRDR, residues 2334-2379, genotype 1) have been shown to be associated with response to treatment [107, 134, 135]. A local accumulation of mutations around the region so-called V3 (variable region 3; codons 2356-2379) within the C-terminal part of the NS5A was reported to correlate with the response to Peg-IFN/ribavirin therapy in HCV genotype 1 isolates [134, 136-138]. Furthermore, genetic analysis of HCV replicon cells which were resistant to IFN treatment revealed that particular substitutions in the NS5A protein (M2174V, T2319A/N, T2242N, F2256L) are associated with the resistance to IFN activity [119]. It has been thought that NS5A blocks IFNs by interacting with PKR, a double-strand RNA-dependent protein kinase. Amino acid substitutions in the NS5A protein may exert the function of PKR. The possibility is also considered that some cellular factors, either alone or in combination with viral factors, contributed to the acquisition of IFN resistance [119].

\section{HCV NS5B}

The NS5B protein of HCV has been one of a number of putative targets of nucleoside analogs, including ribavirin [139]. It has been suggested that the HCV NS5B variant F415Y conferred resistance to ribavirin in HCV genotype 1a infected patients [140]. Substitutions of E124K and I85V identified in the NS5B protein are found to be closely associated with early viral clearance at 8 weeks in patients who were treated with IFN and ribavirin combination therapy and were infected with the HCV genotype $1 \mathrm{~b}$ and had a high level of viremia [141]. Moreover, particular amino acid changes in the NS5B protein of HCV have been shown to correlate with the outcomes of combined-IFN plus ribavirin therapy. Sequence analysis of NS5B revealed that mutations at amino acid residues 309, 333, 338 and 355 of NS5B occurred more 


\section{HCV NS5A protein}

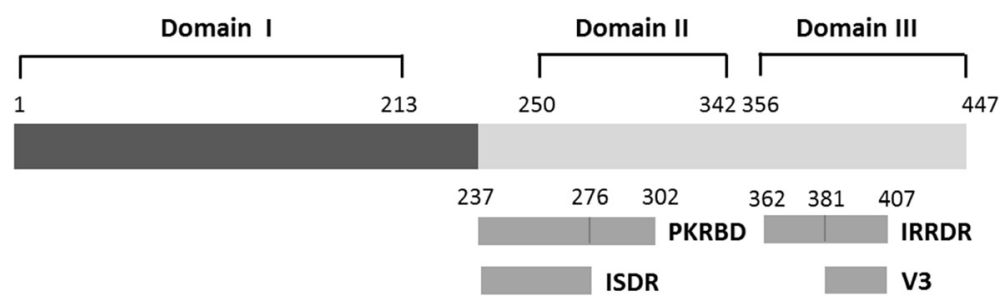

Fig. 3 HCV NS5A protein. Several regions within the NS5A proteins of HCV play a role in the IFN sensitivity of HCV including the interferon-sensitivitydetermining region (ISDR; codons 2209-2248 of HCV genome corresponding to amino acid residues 237-276 of NS5A protein), the interferon and ribavirin resistance determining region (IRRDR; codons 2334-2379 or amino acid residues 362-407 of NS5A), the protein kinase R binding domain (PKRBD; codons 2209-2274 or amino acid residues 237-302 of NS5A), and the variable region 3 (V3; codons 2353-2379 or amino acid residues $381-407$ of NS5A) $[17,98,123,135,137]$

frequently in a group of patients exhibiting an SVR or an end-of-treatment response than in a group of patients showing a negative-response [142]. Furthermore, it has been shown that mutations in NS5B, particularly in the thumb domain and at amino acid position 389, correlate with the viral load and response to IFN therapy of $\mathrm{HCV}$ genotype $1 b$ [143].

\section{HCV mutations associated with the response to antiviral agents}

To date, several DAAs targeting the key components of virus replication have been approved for the treatment of HCV infection. Advances in using these drugs with or without a combination of Peg-IFN/ribavirin have improved SVR rates. However, resistance to antiviral agents of HCV isolates have been documented. The patterns of resistant variants or specific mutations are influenced by multiple parameters including the specific inhibitor, viral genotypes/subtypes and level of drug selective pressure $[144,145]$. In addition, some resistant mutations exist as natural polymorphisms in each genotype/subtype. The pattern of specific mutations resistant to each antiviral agent are shown in Table 1.

\section{Resistance to NS3/4A protease inhibitors}

The FDA has approved three protease inhibitors, including boceprevir, telaprevir and simeprevir for HCV genotype 1 treatment, still, these are not approved to be used in monotherapy. A number of pre-treatment resistance associated amino acid variants (RAVs) and polymorphisms have been shown to be associated with lower responses to the treatment [146]. Both in vitro and in vivo studies showed that several mutations in the NS3 at positions 36, 155, 156, and 168 conferred broad crossresistance affecting all of these protease inhibitors [146-148]. Boceprevir and telaprevir showed broad cross-resistance. The RAVs most frequently associated with boceprevir monotherapy are V36M, T54A/S, V55A, R155K, A156S/T/V and V170A. Similar variants are observed for telaprevir except for V55A and V170A [144, 147, 149]. Moreover, the resistance mutation profile is also influenced by HCV genotypes/subtypes. For example, patients infected with HCV genotype 1a showed main selective amino acid mutations at positions 36 and 155 whereas patients with HCV genotype $1 \mathrm{~b}$ exhibited selective mutations at positions 54, 55, 156 and 170 $[144,145,150-152]$. Substitution of D168Q is generally found in HCV genotype 3 and this natural occurring

Table 1 Amino acid substitutions associated with the resistance to different direct-acting antiviral agents

\begin{tabular}{|c|c|c|}
\hline HCV protein targets & DAAs & Pattern of mutations \\
\hline \multirow[t]{3}{*}{$\overline{N S 3 / 4 A}$} & Boceprevir & V36M/A ${ }^{a}, T 54 A / S^{a}$, V55A ${ }^{a}, R 155 K / T^{a}, A 156 T / S / N^{a}, V 1581, D 168 N, V / 170 A / T / L, L / M 175 L$ \\
\hline & Telapevir & V36G/L/M/A ${ }^{a}$, T54AN/S ${ }^{a}$, S122A/G/R, R155K/T, A156T/S/N ${ }^{a}, \mathrm{D} 168 \mathrm{~A} / \mathrm{H} / \mathrm{T} N$ \\
\hline & Simeprevir & V36M, F43S, Q80Ka , S122A/R, R155T/Ka , A156TN, D168Q/A/H/TN/Ea , V/I170A/T/L \\
\hline \multirow[t]{2}{*}{ NS5A } & Daclatasvir & M28V/A/T, Q30R/E/H, L31F/N/M', Q54H/N/Y, H58D, Q62R/E, A92K/T, Y93H/N/C ${ }^{a}$ \\
\hline & Ledipasvir & M28T, Q30R/H, L31V, Y93H/C \\
\hline NS5B & Sofosbuvir & S282T, I434M, T179A, M289L, I293L, M434T, H479P, L159F/L320F \\
\hline
\end{tabular}

${ }^{a}$ Amino acid substitution represents the significant mutations that are clearly associated with reduced the response to treatment

DAAs direct-acting antiviral agents. Bolded amino acid substitutions indicate mutations frequently found to confer resistance to DAAs. Q80K for genotype 1a; D168Q for genotype 3; Y93H for genotype 1b; S282T for genotypes 1a, 1b, and 2a. Adapted from reviews [144, 145, 148, 149, 157] 
mutation confers resistance to most protease inhibitors [146, 147]. Simeprevir exhibits high antiviral activity against $\mathrm{HCV}$ genotypes 2, 4, 5 and 6 whereas no effect has been observed in genotype 3 [153]. The Q80K mutation is a natural polymorphism detected at baseline in the NS3 sequence. This variant is the most prevalent baseline polymorphism observed in 19-48\% of HCV genotype 1a and appears to be associated with an impaired response to simeprevir [144, 153-155].

\section{Resistance to NS5A inhibitors}

NS5A inhibitors, daclatasvir (BMS-790052) and ledipasvir (GS- 5885), target the binding to domain I of NS5A (amino acid residues 1-213) and this binding leads to blocking of RNA replication and virion assembly [156, 157]. The potent antiviral activity of daclatasvir against HCV replicons from different genotypes has been demonstrated $[158,159]$. However, higher rates of virologic responses to daclatasvir have been observed among HCV genotype $1 \mathrm{~b}$ compared to genotype 1a $[160,161]$. The resistance profile of daclatasvir has been shown to be associated with several amino acid changes within domain I of NS5A at positions M28T, Q30R/H, L31V and Y93H for HCV genotype 1a and $\mathrm{L} 31 \mathrm{H}$ and $\mathrm{Y} 93 \mathrm{H}$ for genotype $1 \mathrm{~b}$. These substitutions have been identified in the in vitro replicon system and show a strong correlation with those observed in the clinical outcome $[157,162]$. In the case of ledipasvir, baseline pre-treatment mutations found in patients with $\mathrm{HCV}$ genotype 1a before being exposed to this drug are M28T, Q30R/H, L31M, Y93C/H. These mutations are associated with reduced susceptibility to treatment response. In the case of genotype $1 \mathrm{~b}, \mathrm{Y} 93 \mathrm{H}$ is the most frequent substitution detected in $100 \%$ of all patients [163].

\section{Resistance to NS5B polymerase inhibitors}

Sofosbuvir was recently approved by the FDA for the treatment of chronic hepatitis C. Substitution of S282T in NS5B has been reported to confer resistance to sofosbuvir in vitro $[164,165]$. By using a replicon system to investigate the antiviral activity of sofosbuvir against different $\mathrm{HCV}$ genotypes including $1 \mathrm{a}, 1 \mathrm{~b}, 2 \mathrm{a}, 2 \mathrm{~b}$, and $3 \mathrm{a}$, it was revealed that the S282T mutation is the most common mutation which conferred resistance to sofosbuvir in genotypes $1 \mathrm{a}, 1 \mathrm{~b}$ and $2 \mathrm{a}$. For genotype $1 \mathrm{a}$ replicons, an additional mutation I434M is observed in combination with S282T. For genotype 2a, at least five additional mutations (T179A, M289L, I293L, M434T, and H479P) have been detected [164, 165]. Recently, mutations of L159F and L320F in the NS5B polymerase that conferred resistance to sofosbuvir have also been reported [166]. Sofosbuvir has a very high barrier to resistance in patients as the resistant mutants are very unfit.

\section{Conclusions}

Treatment of $\mathrm{HCV}$ infection has shown a dramatic improvement in recent years since DAAs have been introduced. A combination of antiviral agents with or without IFN/ribavirin improves treatment success and requires shorter treatment durations for patients infected with diverse HCV genotypes. Although IFN-free therapy has increased high SVR, this regimen is generally more expensive than IFN-based regimen. Hence, some groups of patients may require IFN-containing regimen. The results of IFN-based therapy is likely to remain suboptimal due to host factors such as the host immune response, IL28B phenotype, the presence or absence of cirrhosis, and viral factors of viral load or genotypes. Therefore, HCV mediated-IFN resistance may remain an important factor in the failure of treatment in certain parts of the world and needs to be explored. Understanding of viral mutations and their associations with the clinical outcomes of treatment as well as mechanisms of HCV mediated-IFN resistance should contribute to the improvement of therapeutic guidelines and development of high efficacy and tailor made appropriate regimens for chronic hepatitis $\mathrm{C}$ patients with different genotypes and special cases.

\section{Competing interests}

The authors declare that they have no competing interests.

\section{Authors' contributions}

KK drafted the initial manuscript and approved the final manuscript as submitted; NM critically reviewed and revised the manuscript, and approved the final manuscript as submitted.

\section{Acknowledgements \\ This work was supported by the Faculty of Medicine, Chiang Mai University, Chiang Mai, Thailand.}

Received: 18 September 2015 Accepted: 9 December 2015 Published online: 15 December 2015

References

1. Lyra AC, Fan X, Di Bisceglie AM. Molecular biology and clinical implication of hepatitis C virus. Braz J Med Biol Res. 2004;37:691-5.

2. Moradpour D, Penin F, Rice CM. Replication of hepatitis C virus. Nat Rev Microbiol. 2007;5:453-63.

3. Moriya K, Fujie H, Shintani Y, Yotsuyanagi H, Tsutsumi T, Ishibashi K, et al. The core protein of hepatitis $C$ virus induces hepatocellular carcinoma in transgenic mice. Nat Med. 1998;4:1065-7.

4. Moriya K, Yotsuyanagi H, Shintani Y, Fujie H, Ishibashi K, Matsuura Y, et al. Hepatitis $C$ virus core protein induces hepatic steatosis in transgenic mice. J Gen Virol. 1997;78(Pt 7):1527-31.

5. Nunez O, Fernandez-Martinez A, Majano PL, Apolinario A, Gomez-Gonzalo $\mathrm{M}$, Benedicto I, et al. Increased intrahepatic cyclooxygenase 2, matrix metalloproteinase 2, and matrix metalloproteinase 9 expression is associated with progressive liver disease in chronic hepatitis $C$ virus infection: role of viral core and NS5A proteins. Gut. 2004;53:1665-72.

6. Bartosch B, Vitelli A, Granier C, Goujon C, Dubuisson J, Pascale S, et al. Cell entry of hepatitis $C$ virus requires a set of co-receptors that include the CD81 tetraspanin and the SR-B1 scavenger receptor. J Biol Chem. 2003;278:41624-30.

7. Nielsen SU, Bassendine MF, Burt AD, Bevitt DJ, Toms GL. Characterization of the genome and structural proteins of hepatitis $C$ virus resolved from infected human liver. J Gen Virol. 2004;85:1497-507. 
8. Griffin SD, Beales LP, Clarke DS, Worsfold O, Evans SD, Jaeger J, et al. The p7 protein of hepatitis $C$ virus forms an ion channel that is blocked by the antiviral drug, Amantadine. FEBS Lett. 2003;535:34-8.

9. Pavlovic D, Neville DC, Argaud O, Blumberg B, Dwek RA, Fischer WB, et al. The hepatitis $C$ virus $p 7$ protein forms an ion channel that is inhibited by long-alkyl-chain iminosugar derivatives. Proc Natl Acad Sci U S A. 2003;100:6104-8.

10. Grakoui A, McCourt DW, Wychowski C, Feinstone SM, Rice CM. A second hepatitis C virus-encoded proteinase. Proc Natl Acad Sci U S A. 1993:90:10583-7.

11. Hijikata M, Mizushima H, Akagi T, Mori S, Kakiuchi N, Kato N, et al. Two distinct proteinase activities required for the processing of a putative nonstructural precursor protein of hepatitis C virus. J Virol. 1993;67:4665-75.

12. Hijikata M, Mizushima H, Tanji Y, Komoda Y, Hirowatari Y, Akagi T, et al. Proteolytic processing and membrane association of putative nonstructural proteins of hepatitis C virus. Proc Natl Acad Sci U S A. 1993;90:10773-7.

13. Hijikata M, Shimotohno K. [Mechanisms of hepatitis C viral polyprotein processing]. Uirusu. 1993;43:293-8.

14. Suzich JA, Tamura JK, Palmer-Hill F, Warrener P, Grakoui A, Rice CM, et al. Hepatitis C virus NS3 protein polynucleotide-stimulated nucleoside triphosphatase and comparison with the related pestivirus and flavivirus enzymes. J Virol. 1993;67:6152-8.

15. Bartenschlager R, Lohmann V, Wilkinson T, Koch JO. Complex formation between the NS3 serine-type proteinase of the hepatitis C virus and NS4A and its importance for polyprotein maturation. J Virol. 1995;69:7519-28.

16. Gretton SN, Taylor Al, McLauchlan J. Mobility of the hepatitis C virus NS4B protein on the endoplasmic reticulum membrane and membraneassociated foci. J Gen Virol. 2005;86:1415-21.

17. Tellinghuisen TL, Marcotrigiano J, Gorbalenya AE, Rice CM. The NS5A protein of hepatitis C virus is a zinc metalloprotein. J Biol Chem. 2004;279:48576-87.

18. Tellinghuisen TL, Marcotrigiano J, Rice CM. Structure of the zinc-binding domain of an essential component of the hepatitis $C$ virus replicase. Nature. 2005:435:374-9.

19. Ivashkina N, Wolk B, Lohmann V, Bartenschlager R, Blum HE, Penin F, et al. The hepatitis $C$ virus RNA-dependent RNA polymerase membrane insertion sequence is a transmembrane segment. J Virol. 2002;76:13088-93.

20. Schmidt-Mende J, Bieck E, Hugle T, Penin F, Rice CM, Blum HE, et al. Determinants for membrane association of the hepatitis C virus RNAdependent RNA polymerase. J Biol Chem. 2001;276:44052-63.

21. Cruz-Rivera M, Carpio-Pedroza JC, Escobar-Gutierrez A, Lozano D, VergaraCastaneda A, Rivera-Osorio P, et al. Rapid hepatitis C virus divergence among chronically infected individuals. J Clin Microbiol. 2013;51:629-32.

22. Honegger JR, Kim S, Price AA, Kohout JA, McKnight KL, Prasad MR, et al. Loss of immune escape mutations during persistent HCV infection in pregnancy enhances replication of vertically transmitted viruses. Nat Med. 2013:19:1529-33.

23. Smith DB, Bukh J, Kuiken C, Muerhoff AS, Rice CM, Stapleton JT, et al. Expanded classification of hepatitis $C$ virus into 7 genotypes and 67 subtypes: updated criteria and genotype assignment web resource. Hepatology. 2014;59:318-27.

24. Agha S, Tanaka Y, Saudy N, Kurbanov F, Abo-Zeid M, El-Malky M, et al. Reliability of hepatitis $C$ virus core antigen assay for detection of viremia in HCV genotypes 1, 2, 3, and 4 infected blood donors: a collaborative study between Japan, Egypt, and Uzbekistan. J Med Virol. 2004;73:216-22.

25. Lavanchy D. Evolving epidemiology of hepatitis C virus. Clin Microbiol Infect. 2011;17:107-15.

26. Bartenschlager R, Lohmann V, Penin F. The molecular and structural basis of advanced antiviral therapy for hepatitis C virus infection. Nat Rev Microbiol. 2013;11:482-96.

27. Scarselli $E$, Ansuini $H$, Cerino R, Roccasecca RM, Acali S, Filocamo G, et al. The human scavenger receptor class $B$ type I is a novel candidate receptor for the hepatitis C virus. EMBO J. 2002;21:5017-25.

28. Pileri P, Uematsu Y, Campagnoli S, Galli G, Falugi F, Petracca R, et al. Binding of hepatitis C virus to CD81. Science. 1998;282:938-41.

29. Evans MJ, von Hahn T, Tscherne DM, Syder AJ, Panis M, Wolk B, et al. Claudin-1 is a hepatitis $C$ virus co-receptor required for a late step in entry. Nature. 2007:446:801-5.

30. Ploss A, Evans MJ, Gaysinskaya VA, Panis M, You H, de Jong YP, et al. Human occludin is a hepatitis $C$ virus entry factor required for infection of mouse cells. Nature. 2009;457:882-6.
31. Lupberger J, Zeisel MB, Xiao F, Thumann C, Fofana I, Zona L, et al. EGFR and EphA2 are host factors for hepatitis $C$ virus entry and possible targets for antiviral therapy. Nat Med. 2011;17:589-95.

32. Lohmann V. Hepatitis C virus RNA replication. Curr Top Microbiol Immunol. 2013;369:167-98.

33. Dubuisson J, Cosset FL. Virology and cell biology of the hepatitis C virus life cycle: an update. J Hepatol. 2014;61:S3-s13.

34. Hepatitis C. [http://www.who.int/mediacentre/factsheets/fs164/en/]

35. Brass V, Moradpour D, Blum HE. Molecular virology of hepatitis $C$ virus (HCV): 2006 update. Int J Med Sci. 2006;3:29-34.

36. Stetson DB, Medzhitov R. Type I interferons in host defense. Immunity. 2006;25:373-81.

37. Heim MH, Thimme R. Innate and adaptive immune responses in HCV infections. J Hepatol. 2014;61:S14-25.

38. Horner SM. Activation and evasion of antiviral innate immunity by hepatitis C virus. J Mol Biol. 2014;426:1198-209.

39. Carithers Jr RL, Emerson SS. Therapy of hepatitis C: meta-analysis of interferon alfa-2b trials. Hepatology. 1997;26:83s-8s.

40. Hoofnagle JH, Mullen KD, Jones DB, Rustgi V, Di Bisceglie A, Peters M, et al. Treatment of chronic non-A,non-B hepatitis with recombinant human alpha interferon. A preliminary report. N Engl J Med. 1986;315:1575-8.

41. Te HS, Randall G, Jensen DM. Mechanism of action of ribavirin in the treatment of chronic hepatitis C. Gastroenterol Hepatol (N Y). 2007:3:218-25.

42. McHutchison JG, Gordon SC, Schiff ER, Shiffman ML, Lee WM, Rustgi VK, et $a$ l. Interferon alfa-2b alone or in combination with ribavirin as initial treatment for chronic hepatitis C. Hepatitis Interventional Therapy Group. N Engl J Med. 1998;339:1485-92.

43. McHutchison JG, Poynard T. Combination therapy with interferon plus ribavirin for the initial treatment of chronic hepatitis C. Semin Liver Dis. 1999;19 Suppl 1:57-65.

44. Scott LJ, Perry CM. Interferon-alpha-2b plus ribavirin: a review of its use in the management of chronic hepatitis C. Drugs. 2002;62:507-56.

45. Feld JJ, Hoofnagle JH. Mechanism of action of interferon and ribavirin in treatment of hepatitis C. Nature. 2005;436:967-72.

46. Keating GM, Plosker GL. Peginterferon alpha-2a (40KD) plus ribavirin: a review of its use in the management of patients with chronic hepatitis C and persistently 'normal' ALT levels. Drugs. 2005;65:521-36.

47. Escudero A, Rodriguez F, Serra MA, Del Olmo JA, Montes F, Rodrigo JM. Pegylated alpha-interferon-2a plus ribavirin compared with pegylated alpha-interferon-2b plus ribavirin for initial treatment of chronic hepatitis C virus: prospective, non-randomized study. J Gastroenterol Hepatol. 2008;23:861-6.

48. Fried MW, Shiffman ML, Reddy KR, Smith C, Marinos G, Goncales Jr FL, et al. Peginterferon alfa-2a plus ribavirin for chronic hepatitis $C$ virus infection. N Engl J Med. 2002;347:975-82.

49. Hadziyannis SJ, Sette Jr H, Morgan TR, Balan V, Diago M, Marcellin P, et al. Peginterferon-alpha2a and ribavirin combination therapy in chronic hepatitis $\mathrm{C}$ : a randomized study of treatment duration and ribavirin dose. Ann Intern Med. 2004;140:346-55.

50. Manns MP, McHutchison JG, Gordon SC, Rustgi VK, Shiffman M, Reindollar R, et al. Peginterferon alfa-2b plus ribavirin compared with interferon alfa- $2 \mathrm{~b}$ plus ribavirin for initial treatment of chronic hepatitis $\mathrm{C}$ : a randomised trial. Lancet. 2001;358:958-65.

51. Pawlotsky JM. Mechanisms of antiviral treatment efficacy and failure in chronic hepatitis C. Antiviral Res. 2003:59:1-11.

52. Wohnsland A, Hofmann WP, Sarrazin C. Viral determinants of resistance to treatment in patients with hepatitis C. Clin Microbiol Rev. 2007;20:23-38.

53. Cavalcante LN, Lyra AC. Predictive factors associated with hepatitis C antiviral therapy response. World J Hepatol. 2015;7:1617-31.

54. Zhu Y, Chen S. Antiviral treatment of hepatitis $C$ virus infection and factors affecting efficacy. World J Gastroenterol. 2013;19:8963-73.

55. Sulkowski MS, Cooper C, Hunyady B, Jia J, Ogurtsov P, Peck-Radosavljevic M, et al. Management of adverse effects of Peg-IFN and ribavirin therapy for hepatitis C. Nat Rev Gastroenterol Hepatol. 2011;8:212-23.

56. Bacon BR, Gordon SC, Lawitz E, Marcellin P, Vierling JM, Zeuzem S, et al. Boceprevir for previously treated chronic HCV genotype 1 infection. N Engl Med. 2011:364:1207-17.

57. Jacobson IM, McHutchison JG, Dusheiko G, Di Bisceglie AM, Reddy KR, Bzowej NH, et al. Telaprevir for previously untreated chronic hepatitis C virus infection. N Engl J Med. 2011;364:2405-16. 
58. Poordad F, McCone Jr J, Bacon BR, Bruno S, Manns MP, Sulkowski MS, et al. Boceprevir for untreated chronic HCV genotype 1 infection. N Engl J Med. 2011;364:1195-206.

59. Zeuzem S, Andreone P, Pol S, Lawitz E, Diago M, Roberts S, et al. Telaprevir for retreatment of HCV infection. N Engl J Med. 2011;364:2417-28.

60. Kronenberger B, Zeuzem S. New developments in HCV therapy. J Viral Hepat. 2012;19 Suppl 1:48-51.

61. Rosenquist A, Samuelsson B, Johansson PO, Cummings MD, Lenz O, Raboisson P, et al. Discovery and development of simeprevir (TMC435), a HCV NS3/4A protease inhibitor. J Med Chem. 2014;57:1673-93.

62. Fried MW, Buti M, Dore GJ, Flisiak R, Ferenci P, Jacobson I, et al. Once-daily simeprevir (TMC435) with pegylated interferon and ribavirin in treatmentnaive genotype 1 hepatitis C: the randomized PILLAR study. Hepatology. 2013;58:1918-29.

63. Jacobson IM, Dore GJ, Foster GR, Fried MW, Radu M, Rafalsky W, et al. Simeprevir with pegylated interferon alfa 2a plus ribavirin in treatmentnaive patients with chronic hepatitis C virus genotype 1 infection (QUEST-1): a phase 3, randomised, double-blind, placebo-controlled trial. Lancet. 2014;384:403-13.

64. Manns MP, von Hahn T. Novel therapies for hepatitis C - one pill fits all? Nat Rev Drug Discov. 2013:12:595-610.

65. Link JO, Taylor JG, Xu L, Mitchell M, Guo H, Liu H, et al. Discovery of ledipasvir (GS-5885): a potent, once-daily oral NS5A inhibitor for the treatment of hepatitis C virus infection. J Med Chem. 2014;57:2033-46.

66. DeGoey DA, Randolph JT, Liu D, Pratt J, Hutchins C, Donner P, et al. Discovery of ABT-267, a pan-genotypic inhibitor of HCV NS5A. J Med Chem. 2014;57:2047-57.

67. Gao M, Nettles RE, Belema M, Snyder LB, Nguyen VN, Fridell RA, et al. Chemical genetics strategy identifies an HCV NS5A inhibitor with a potent clinical effect. Nature. 2010;465:96-100.

68. Pol S, Ghalib RH, Rustgi VK, Martorell C, Everson GT, Tatum HA, et al. Daclatasvir for previously untreated chronic hepatitis $C$ genotype- 1 infection: a randomised, parallel-group, double-blind, placebo-controlled, dose-finding, phase 2a trial. Lancet Infect Dis. 2012;12:671-7.

69. Chow J, Liu Y, Comstock K, Brandl M, Lin F, Li F, et al. Isolation and identification of ester impurities in RG7128, an HCV polymerase inhibitor. J Pharm Biomed Anal. 2010;53:710-6.

70. Sofia MJ, Bao D, Chang W, Du J, Nagarathnam D, Rachakonda S, et al. Discovery of a beta-d-2'-deoxy-2'-alpha-fluoro-2'-beta-C-methyluridine nucleotide prodrug (PSI-7977) for the treatment of hepatitis C virus. J Med Chem. 2010;53:7202-18.

71. Holler TP, Parkinson T, Pryde DC. Targeting the non-structural proteins of hepatitis C virus: beyond hepatitis C virus protease and polymerase. Expert Opin Drug Discov. 2009;4:293-314.

72. Koch U, Narjes F. Recent progress in the development of inhibitors of the hepatitis C virus RNA-dependent RNA polymerase. Curr Top Med Chem. 2007:7:1302-29.

73. Gentile I, Buonomo AR, Borgia G. Dasabuvir: a non-nucleoside inhibitor of NS5B for the treatment of hepatitis C virus infection. Rev Recent Clin Trials. 2014;9:115-23

74. Gane EJ, Stedman CA, Hyland RH, Ding X, Svarovskaia E, Symonds WT, et al. Nucleotide polymerase inhibitor sofosbuvir plus ribavirin for hepatitis C. N Engl J Med. 2013;368:34-44.

75. Lawitz E, Mangia A, Wyles D, Rodriguez-Torres M, Hassanein T, Gordon SC, et al. Sofosbuvir for previously untreated chronic hepatitis $\mathrm{C}$ infection. $\mathrm{N}$ Engl J Med. 2013;368:1878-87.

76. Kowdley KV, Lawitz E, Crespo I, Hassanein T, Davis MN, DeMicco M, et al. Sofosbuvir with pegylated interferon alfa-2a and ribavirin for treatmentnaive patients with hepatitis C genotype-1 infection (ATOMIC): an openlabel, randomised, multicentre phase 2 trial. Lancet. 2013;381:2100-7.

77. Omata M, Nishiguchi S, Ueno Y, Mochizuki H, Izumi N, Ikeda F, et al. Sofosbuvir plus ribavirin in Japanese patients with chronic genotype 2 HCV infection: an open-label, phase 3 trial. J Viral Hepat. 2014;21:762-8.

78. Gritsenko D, Hughes G. Ledipasvir/Sofosbuvir (harvoni): improving options for hepatitis C virus infection. P T. 2015;40:256-76.

79. Keating GM. Ledipasvir/Sofosbuvir: a review of its use in chronic hepatitis C. Drugs. 2015;75(6):675-85.

80. Gale Jr M. Effector genes of interferon action against hepatitis $C$ virus. Hepatology. 2003;37:975-8.

81. Gilmour KC, Reich NC. Signal transduction and activation of gene transcription by interferons. Gene Expr. 1995;5:1-18.
82. Taylor DR, Shi ST, Lai MM. Hepatitis C virus and interferon resistance. Microbes Infect. 2000;2:1743-56.

83. Hofmann WP, Zeuzem S, Sarrazin C. Hepatitis C virus-related resistance mechanisms to interferon alpha-based antiviral therapy. J Clin Virol. 2005;32:86-91.

84. Gale Jr M, Foy EM. Evasion of intracellular host defence by hepatitis C virus. Nature. 2005:436:939-45.

85. Bode JG, Ludwig S, Ehrhardt C, Albrecht U, Erhardt A, Schaper F, et al. IFNalpha antagonistic activity of HCV core protein involves induction of suppressor of cytokine signaling-3. FASEB J. 2003;17:488-90.

86. Shao RX, Zhang L, Peng LF, Sun E, Chung WJ, Jang JY, et al. Suppressor of cytokine signaling 3 suppresses hepatitis C virus replication in an mTORdependent manner. J Virol. 2010:84:6060-9.

87. de Lucas S, Bartolome J, Carreno V. Hepatitis C virus core protein downregulates transcription of interferon-induced antiviral genes. J Infect Dis. 2005;191:93-9.

88. Lin W, Choe WH, Hiasa Y, Kamegaya Y, Blackard JT, Schmidt EV, et al. Hepatitis C virus expression suppresses interferon signaling by degrading STAT1. Gastroenterology. 2005;128:1034-41.

89. Lin W, Kim SS, Yeung E, Kamegaya Y, Blackard JT, Kim KA, et al. Hepatitis C virus core protein blocks interferon signaling by interaction with the STAT1 SH2 domain. J Virol. 2006;80:9226-35.

90. Taylor DR, Shi ST, Romano PR, Barber GN, Lai MM. Inhibition of the interferon-inducible protein kinase PKR by HCV E2 protein. Science. 1999:285:107-10.

91. Horner SM, Gale Jr M. Regulation of hepatic innate immunity by hepatitis C virus. Nat Med. 2013;19:879-88.

92. Li XD, Sun L, Seth RB, Pineda G, Chen ZJ. Hepatitis C virus protease NS3/4A cleaves mitochondrial antiviral signaling protein off the mitochondria to evade innate immunity. Proc Natl Acad Sci U S A. 2005;102:17717-22.

93. Meylan E, Curran J, Hofmann K, Moradpour D, Binder M, Bartenschlager R, et al. Cardif is an adaptor protein in the RIG-I antiviral pathway and is targeted by hepatitis C virus. Nature. 2005;437:1167-72.

94. Li K, Foy E, Ferreon JC, Nakamura M, Ferreon AC, Ikeda M, et al. Immune evasion by hepatitis C virus NS3/4A protease-mediated cleavage of the Toll-like receptor 3 adaptor protein TRIF. Proc Natl Acad Sci U S A. 2005; 102:2992-7.

95. Foy E, Li K, Sumpter Jr R, Loo YM, Johnson CL, Wang C, et al. Control of antiviral defenses through hepatitis $C$ virus disruption of retinoic acidinducible gene-I signaling. Proc Natl Acad Sci U S A. 2005;102:2986-91.

96. Foy E, Li K, Wang C, Sumpter Jr R, Ikeda M, Lemon SM, et al. Regulation of interferon regulatory factor- 3 by the hepatitis $C$ virus serine protease. Science. 2003;300:1145-8.

97. Xu J, Liu S, Xu Y, Tien P, Gao G. Identification of the nonstructural protein $4 \mathrm{~B}$ of hepatitis $\mathrm{C}$ virus as a factor that inhibits the antiviral activity of interferon-alpha. Virus Res. 2009;141:55-62.

98. Gale Jr MJ, Korth MJ, Katze MG. Repression of the PKR protein kinase by the hepatitis C virus NS5A protein: a potential mechanism of interferon resistance. Clin Diagn Virol. 1998:10:157-62.

99. Gale Jr MJ, Korth MJ, Tang NM, Tan SL, Hopkins DA, Dever TE, et al. Evidence that hepatitis $C$ virus resistance to interferon is mediated through repression of the PKR protein kinase by the nonstructural $5 \mathrm{~A}$ protein. Virology. 1997;230:217-27.

100. Gong GZ, Cao J, Jiang YF, Zhou Y, Liu B. Hepatitis C virus non-structural 5A abrogates signal transducer and activator of transcription-1 nuclear translocation induced by IFN-alpha through dephosphorylation. World J Gastroenterol. 2007:13:4080-4.

101. Kang SM, Won SJ, Lee GH, Lim YS, Hwang SB. Modulation of interferon signaling by hepatitis $C$ virus non-structural 5A protein: implication of genotypic difference in interferon treatment. FEBS Lett. 2010;584:4069-76.

102. Kumthip K, Chusri $P$, Jilg N, Zhao L, Fusco DN, Zhao H, et al. Hepatitis C virus NS5A disrupts STAT1 phosphorylation and suppresses type I interferon signaling. J Virol. 2012:86:8581-91.

103. Lan $\mathrm{KH}$, Lan $\mathrm{KL}$, Lee WP, Sheu ML, Chen MY, Lee $Y L$, et al. HCV NS5A inhibits interferon-alpha signaling through suppression of STAT1 phosphorylation in hepatocyte-derived cell lines. J Hepatol. 2007;46:759-67.

104. Akuta N, Suzuki F, Sezaki H, Suzuki Y, Hosaka T, Someya T, et al. Predictive factors of virological non-response to interferon-ribavirin combination therapy for patients infected with hepatitis $C$ virus of genotype $1 \mathrm{~b}$ and high viral load. J Med Virol. 2006;78:83-90. 
105. Akuta N, Suzuki F, Sezaki H, Suzuki Y, Hosaka T, Someya T, et al. Association of amino acid substitution pattern in core protein of hepatitis $C$ virus genotype $1 \mathrm{~b}$ high viral load and non-virological response to interferonribavirin combination therapy. Intervirology. 2005;48:372-80.

106. Hayashi K, Katano Y, Ishigami M, Itoh A, Hirooka Y, Nakano I, et al. Mutations in the core and NS5A region of hepatitis $C$ virus genotype $1 \mathrm{~b}$ and correlation with response to pegylated-interferon-alpha $2 \mathrm{~b}$ and ribavirin combination therapy. J Viral Hepat. 2011;18:280-6.

107. El-Shamy A, Kim SR, Ide YH, Sasase N, Imoto S, Deng L, et al. Polymorphisms of hepatitis $C$ virus non-structural protein $5 \mathrm{~A}$ and core protein and clinical outcome of pegylated-interferon/ribavirin combination therapy. Intervirology. 2012;55:1-11.

108. Funaoka Y, Sakamoto N, Suda G, Itsui Y, Nakagawa M, Kakinuma S, et al. Analysis of interferon signaling by infectious hepatitis $C$ virus clones with substitutions of core amino acids 70 and 91. J Virol. 2011;85:5986-94.

109. Abid K, Quadri R, Negro F. Hepatitis C virus, the E2 envelope protein, and alpha-interferon resistance. Science. 2000;287:1555.

110. Berg T, Mas Marques A, Hohne M, Wiedenmann B, Hopf U, Schreier E. Mutations in the E2-PePHD and NS5A region of hepatitis $C$ virus type 1 and the dynamics of hepatitis $C$ viremia decline during interferon alfa treatment. Hepatology. 2000;32:1386-95.

111. Murphy MD, Rosen HR, Marousek GI, Chou S. Analysis of sequence configurations of the ISDR, PKR-binding domain, and V3 region as predictors of response to induction interferon-alpha and ribavirin therapy in chronic hepatitis C infection. Dig Dis Sci. 2002;47:1195-205.

112. Sarrazin C, Kornetzky I, Ruster B, Lee JH, Kronenberger B, Bruch K, et al. Mutations within the E2 and NS5A protein in patients infected with hepatitis $C$ virus type $3 \mathrm{a}$ and correlation with treatment response. Hepatology. 2000;31:1360-70.

113. Saito T, Ito T, Ishiko H, Yonaha M, Morikawa K, Miyokawa A, et al. Sequence analysis of PePHD within HCV E2 region and correlation with resistance of interferon therapy in Japanese patients infected with HCV genotypes 2a and 2b. Am J Gastroenterol. 2003;98:1377-83.

114. Ukai K, Ishigami M, Yoshioka K, Kawabe N, Katano Y, Hayashi K, et al. Mutations in carboxy-terminal part of E2 including PKR/elF2alpha phosphorylation homology domain and interferon sensitivity determining region of nonstructural $5 \mathrm{~A}$ of hepatitis $\mathrm{C}$ virus $1 \mathrm{~b}$ : their correlation with response to interferon monotherapy and viral load. World J Gastroenterol. 2006;12:3722-8.

115. Serre SB, Krarup HB, Bukh J, Gottwein JM. Identification of alpha interferoninduced envelope mutations of hepatitis $C$ virus in vitro associated with increased viral fitness and interferon resistance. J Virol. 2013;87:12776-93.

116. Sarrazin C, Mihm U, Herrmann E, Welsch C, Albrecht M, Sarrazin U, et al. Clinical significance of in vitro replication-enhancing mutations of the hepatitis $\mathrm{C}$ virus $(\mathrm{HCV})$ replicon in patients with chronic HCV infection. J Infect Dis. 2005;192:1710-9.

117. Donlin MJ, Cannon NA, Yao E, Li J, Wahed A, Taylor MW, et al. Pretreatment sequence diversity differences in the full-length hepatitis $C$ virus open reading frame correlate with early response to therapy. J Virol. 2007;81:8211-24.

118. Chusri P, Kumthip K, Pantip C, Thongsawat S, O'Brien A, Maneekarn N. Influence of amino acid variations in the NS3, NS4A and NS4B of HCV genotypes $1 \mathrm{a}, 1 \mathrm{~b}, 3 \mathrm{a}, 3 \mathrm{~b}$ and $6 \mathrm{f}$ on the response to pegylated interferon and ribavirin combination therapy. Virus Res. 2015;196:37-43.

119. Numba K, Naka K, Dansako H, Nozaki A, Ikeda M, Shiratori Y, et al. Establishment of hepatitis C virus replicon cell lines possessing interferonresistant phenotype. Biochem Biophys Res Commun. 2004;323:299-309.

120. Morikawa K, Lange CM, Gouttenoire J, Meylan E, Brass V, Penin F, et al. Nonstructural protein 3-4A: the Swiss army knife of hepatitis $C$ virus. J Viral Hepat. 2011;18:305-15.

121. Horner SM, Park HS, Gale Jr M. Control of innate immune signaling and membrane targeting by the Hepatitis $C$ virus NS3/4A protease are governed by the NS3 helix alpha0. J Virol. 2012;86:3112-20.

122. Welker MW, Hofmann WP, Welsch C, von Wagner M, Herrmann E, Lengauer $T$, et al. Correlation of amino acid variations within nonstructural $4 B$ protein with initial viral kinetics during interferon-alpha-based therapy in HCV-1binfected patients. J Viral Hepat. 2007;14:338-49.

123. Enomoto N, Sakuma I, Asahina Y, Kurosaki M, Murakami T, Yamamoto C, et al. Comparison of full-length sequences of interferon-sensitive and resistant hepatitis $C$ virus $1 \mathrm{~b}$. Sensitivity to interferon is conferred by amino acid substitutions in the NS5A region. J Clin Invest. 1995;96:224-30.
124. Enomoto N, Sakuma I, Asahina Y, Kurosaki M, Murakami T, Yamamoto C, et al. Mutations in the nonstructural protein $5 \mathrm{~A}$ gene and response to interferon in patients with chronic hepatitis C virus $1 \mathrm{~b}$ infection. N Engl J Med. 1996:334:77-81.

125. Chayama K, Tsubota A, Kobayashi M, Okamoto K, Hashimoto M, Miyano Y, et al. Pretreatment virus load and multiple amino acid substitutions in the interferon sensitivity-determining region predict the outcome of interferon treatment in patients with chronic genotype $1 \mathrm{~b}$ hepatitis $C$ virus infection. Hepatology. 1997;25:745-9.

126. Murayama M, Katano Y, Nakano I, Ishigami M, Hayashi K, Honda T, et al. A mutation in the interferon sensitivity-determining region is associated with responsiveness to interferon-ribavirin combination therapy in chronic hepatitis patients infected with a Japan-specific subtype of hepatitis $C$ virus genotype 1B. J Med Virol. 2007;79:35-40.

127. Shen C, Hu T, Shen L, Gao L, Xie W, Zhang J. Mutations in ISDR of NS5A gene influence interferon efficacy in Chinese patients with chronic hepatitis C virus genotype 1b infection. J Gastroenterol Hepatol. 2007;22:1898-903.

128. Watanabe H, Enomoto N, Nagayama K, Izumi N, Marumo F, Sato C, et al. Number and position of mutations in the interferon (IFN) sensitivitydetermining region of the gene for nonstructural protein $5 \mathrm{~A}$ correlate with IFN efficacy in hepatitis C virus genotype $1 \mathrm{~b}$ infection. J Infect Dis. 2001;183:1195-203.

129. Chung RT, Monto A, Dienstag JL, Kaplan LM. Mutations in the NS5A region do not predict interferon-responsiveness in american patients infected with genotype 1b hepatitis C virus. J Med Virol. 1999;58:353-8.

130. Duverlie G, Khorsi H, Castelain S, Jaillon O, Izopet J, Lunel F, et al. Sequence analysis of the NS5A protein of European hepatitis $C$ virus $1 \mathrm{~b}$ isolates and relation to interferon sensitivity. J Gen Virol. 1998;79(Pt 6):1373-81.

131. Munoz de Rueda P, Casado J, Paton R, Quintero D, Palacios A, Gila A, et al. Mutations in E2-PePHD, NS5A-PKRBD, NS5A-ISDR, and NS5A-V3 of hepatitis $C$ virus genotype 1 and their relationships to pegylated interferon-ribavirin treatment responses. J Virol. 2008;82:6644-53.

132. Zeuzem S, Lee JH, Roth WK. Mutations in the nonstructural 5A gene of European hepatitis $C$ virus isolates and response to interferon alfa. Hepatology. 1997;25:740-4.

133. Pascu M, Martus $P$, Hohne M, Wiedenmann B, Hopf U, Schreier E, et al. Sustained virological response in hepatitis $C$ virus type $1 \mathrm{~b}$ infected patients is predicted by the number of mutations within the NS5A-ISDR: a metaanalysis focused on geographical differences. Gut. 2004;53:1345-51.

134. El-Shamy A, Sasayama M, Nagano-Fujii M, Sasase N, Imoto S, Kim SR, et al. Prediction of efficient virological response to pegylated interferon/ribavirin combination therapy by NS5A sequences of hepatitis C virus and anti-NS5A antibodies in pre-treatment sera. Microbiol Immunol. 2007;51:471-82.

135. Kozuka R, Enomoto M, Hai H, Ogawa T, Nakaya M, Hagihara A, et al. Changes in sequences of core region, interferon sensitivity-determining region and interferon and ribavirin resistance-determining region of hepatitis $C$ virus genotype 1 during interferon-alpha and ribavirin therapy, and efficacy of retreatment. Hepatol Res. 2012;42:1157-67.

136. El-Shamy A, Nagano-Fujii M, Sasase N, Imoto S, Kim SR, Hotta H. Sequence variation in hepatitis $\mathrm{C}$ virus nonstructural protein $5 \mathrm{~A}$ predicts clinical outcome of pegylated interferon/ribavirin combination therapy. Hepatology. 2008;48:38-47.

137. Kumthip K, Pantip C, Chusri P, Thongsawat S, O'Brien A, Nelson KE, et al. Correlation between mutations in the core and NS5A genes of hepatitis $C$ virus genotypes $1 \mathrm{a}, 1 \mathrm{~b}, 3 \mathrm{a}, 3 \mathrm{~b}, 6 \mathrm{f}$ and the response to pegylated interferon and ribavirin combination therapy. J Viral Hepat. 2011;18:e117-125.

138. Nousbaum J, Polyak SJ, Ray SC, Sullivan DG, Larson AM, Carithers Jr RL, et al. Prospective characterization of full-length hepatitis C virus NS5A quasispecies during induction and combination antiviral therapy. J Virol. 2000;74:9028-38.

139. Lohmann V, Korner F, Herian U, Bartenschlager R. Biochemical properties of hepatitis C virus NS5B RNA-dependent RNA polymerase and identification of amino acid sequence motifs essential for enzymatic activity. J Virol. 1997;71:8416-28.

140. Young KC, Lindsay KL, Lee KJ, Liu WC, He JW, Milstein SL, et al. Identification of a ribavirin-resistant NS5B mutation of hepatitis $C$ virus during ribavirin monotherapy. Hepatology. 2003;38:869-78.

141. Kumagai N, Takahashi N, Kinoshita M, Tsunematsu S, Tsuchimoto K, Saito $\mathrm{H}$, et al. Polymorphisms of NS5B protein relates to early clearance of hepatitis $C$ virus by interferon plus ribavirin: a pilot study. J Viral Hepat. $2004 ; 11: 225-35$ 
142. Hamano K, Sakamoto N, Enomoto N, Izumi N, Asahina Y, Kurosaki M, et al. Mutations in the NS5B region of the hepatitis $C$ virus genome correlate with clinical outcomes of interferon-alpha plus ribavirin combination therapy. J Gastroenterol Hepatol. 2005;20:1401-9.

143. Watanabe K, Yoshioka K, Yano M, Ishigami M, Ukai K, Ito H, et al. Mutations in the nonstructural region $5 B$ of hepatitis $C$ virus genotype $1 \mathrm{~b}$ : their relation to viral load, response to interferon, and the nonstructural region 5A. J Med Virol. 2005;75:504-12.

144. Sarrazin C, Zeuzem S. Resistance to direct antiviral agents in patients with hepatitis C virus infection. Gastroenterology. 2010;138:447-62.

145. Vermehren J, Sarrazin C. The role of resistance in HCV treatment. Best Pract Res Clin Gastroenterol. 2012;26:487-503.

146. Poveda E, Wyles DL, Mena A, Pedreira JD, Castro-Iglesias A, Cachay E. Update on hepatitis $C$ virus resistance to direct-acting antiviral agents. Antiviral Res. 2014;108:181-91.

147. Kieffer TL, George S. Resistance to hepatitis $C$ virus protease inhibitors. Curr Opin Virol. 2014;8:16-21.

148. Preciado MV, Valva P, Escobar-Gutierrez A, Rahal P, Ruiz-Tovar K, Yamasaki L, et al. Hepatitis $C$ virus molecular evolution: transmission, disease progression and antiviral therapy. World J Gastroenterol. 2014;20:15992-6013.

149. Wyles DL. Antiviral resistance and the future landscape of hepatitis C virus infection therapy. J Infect Dis. 2013;207 Suppl 1:S33-39.

150. Kieffer TL, De Meyer S, Bartels DJ, Sullivan JC, Zhang EZ, Tigges A, et al. Hepatitis $C$ viral evolution in genotype 1 treatment-naive and treatmentexperienced patients receiving telaprevir-based therapy in clinical trials. PLoS One. 2012;7:e34372.

151. Barnard RJ, Howe JA, Ogert RA, Zeuzem S, Poordad F, Gordon SC, et al. Analysis of boceprevir resistance associated amino acid variants (RAVs) in two phase 3 boceprevir clinical studies. Virology. 2013;444:329-36.

152. Ogert RA, Howe JA, Vierling JM, Kwo PY, Lawitz EJ, McCone J, et al. Resistance-associated amino acid variants associated with boceprevir plus pegylated interferon-alpha2b and ribavirin in patients with chronic hepatitis C in the SPRINT-1 trial. Antivir Ther. 2013;18:387-97.

153. Moreno C, Berg T, Tanwandee T, Thongsawat S, Van Vlierberghe H, Zeuzem S, et al. Antiviral activity of TMC435 monotherapy in patients infected with HCV genotypes 2-6: TMC435-C202, a phase lla, open-label study. J Hepatol. 2012;56:1247-53.

154. Shah N, Pierce T, Kowdley KV. Review of direct-acting antiviral agents for the treatment of chronic hepatitis C. Expert Opin Investig Drugs. 2013;22:1107-21.

155. Shepherd SJ, Abdelrahman T, MacLean AR, Thomson EC, Aitken C, Gunson RN. Prevalence of HCV NS3 pre-treatment resistance associated amino acid variants within a Scottish cohort. J Clin Virol. 2015;65:50-3.

156. Guedj J, Dahari H, Rong L, Sansone ND, Nettles RE, Cotler SJ, et al. Modeling shows that the NS5A inhibitor daclatasvir has two modes of action and yields a shorter estimate of the hepatitis C virus half-life. Proc Natl Acad Sci U S A. 2013:110:3991-6.

157. Lim PJ, Gallay PA. Hepatitis C NS5A protein: two drug targets within the same protein with different mechanisms of resistance. Curr Opin Virol. 2014;8:30-7.

158. Fridell RA, Qiu D, Wang C, Valera L, Gao M. Resistance analysis of the hepatitis C virus NS5A inhibitor BMS-790052 in an in vitro replicon system. Antimicrob Agents Chemother. 2010;54:3641-50.

159. Fridell RA, Wang C, Sun JH, O'Boyle 2nd DR, Nower P, Valera L, et al. Genotypic and phenotypic analysis of variants resistant to hepatitis $C$ virus nonstructural protein 5A replication complex inhibitor BMS-790052 in humans: in vitro and in vivo correlations. Hepatology. 2011;54:1924-35.

160. Sulkowski MS, Gardiner DF, Rodriguez-Torres M, Reddy KR, Hassanein T, Jacobson I, et al. Daclatasvir plus sofosbuvir for previously treated or untreated chronic HCV infection. N Engl J Med. 2014;370:211-21.

161. Wang C, Sun JH, O'Boyle 2nd DR, Nower P, Valera L, Roberts S, et al. Persistence of resistant variants in hepatitis $C$ virus-infected patients treated with the NS5A replication complex inhibitor daclatasvir. Antimicrob Agents Chemother. 2013;57:2054-65.

162. Asselah T. NS5A inhibitors: a new breakthrough for the treatment of chronic hepatitis C. J Hepatol. 2011;54:1069-72.

163. Gao M. Antiviral activity and resistance of HCV NS5A replication complex inhibitors. Curr Opin Virol. 2013:3:514-20.

164. Lam AM, Espiritu C, Bansal S, Micolochick Steuer HM, Niu C, Zennou V, et al. Genotype and subtype profiling of PSI-7977 as a nucleotide inhibitor of hepatitis C virus. Antimicrob Agents Chemother. 2012;56:3359-68.
165. Gotte M. Resistance to nucleotide analogue inhibitors of hepatitis $C$ virus NS5B: mechanisms and clinical relevance. Curr Opin Virol. 2014;8:104-8.

166. Tong X, Le Pogam S, Li L, Haines K, Piso K, Baronas V, et al. In vivo emergence of a novel mutant L159F/L320F in the NS5B polymerase confers low-level resistance to the HCV polymerase inhibitors mericitabine and sofosbuvir. J Infect Dis. 2014;209:668-75.

\section{Submit your next manuscript to BioMed Central and we will help you at every step:}

- We accept pre-submission inquiries

- Our selector tool helps you to find the most relevant journal

- We provide round the clock customer support

- Convenient online submission

- Thorough peer review

- Inclusion in PubMed and all major indexing services

- Maximum visibility for your research

Submit your manuscript at www.biomedcentral.com/submit
C Biomed Central 